\title{
ENTREPRENEURIAL EDUCATION DAN \\ ENTREPRENEURIAL INTENTION: SOCIAL SUPPORT SEBAGAI MODERASI VARIABEL
}

\begin{abstract}
Research in entrepreneurship field has magnetized the interest of many researchers as a tool of development for many countries. This study examined the impact of social support as moderating variable between entrepreneurial education and entrepreneurial intention in Bandung. To achieve the above objective a survey of over 130 graduate students at four of the State University in Bandung. Data analysis using the Statistical Product Solution Service. Furthermore, multivariate analysis of variance was applied on the data. The results demonstrate that social support as moderating variable between entrepreneurial education and entrepreneurial intention. There is a positive moderating effect of social support on the entrepreneurial education and entrepreneurial intention. High social support is associated with a positive relation entrepreneurial education and entrepreneurial intention, while low social support is associated with no relation or even a negative relation between entrepreneurial education and entrepreneurial intention.
\end{abstract}

Key Words: Entrepreneurial Education, Entrepreneurial Intention and Social Support

Yulia Fithriyani Rahmah

Dosen Manajemen FISIP UIN SGD Bandung

\section{A. Pendahuluan}

Indonesia merupakan negara dengan jumlah penduduk yang sangat besar. Penduduk yang besar dengan daya beli yang terus meningkat adalah pasar yang potensial. Indonesia tengah berada dalam periode transisi struktur penduduk usia produktif. Kondisi ini semakin penting untuk penyediaan lapangan kerja agar perekonomian dapat memanfaatkan secara maksimal besarnya porsi penduduk usia produktif. Lebih penting lagi, bila tingkat pendidikan secara umum diasumsikan terus membaik, produktivitas perekonomian negara ini sesungguhnya dalam kondisi premium, dimana hal tersebut akan sangat bermanfaat untuk tujuan percepatan maupun perluasan pembangunan ekonomi.

Kewirausahaan merupakan faktor penting dalam pembentukan kemajuan suatu Negara. Wirausaha akan menyediakan sumber-sumber 
pendapatan ketika ekonomi lesu dan belum bisa memberikan pekerjaanpekerjaan atau alternative gaji (Rhasid, et, al, 2012). Banyak penelitian yang menerangkan bahwa usaha mikro kecil menengah berkontribusi pada kreasi, inovasi dan pertumbuhan suatu Negara. Seseorang yang memiliki pengalaman pekerjaan dapat mempengaruhi tingkat pengambilan keputusan untuk memulai suatu bisnis. Pendidikan wirausaha menjadi komponen yang sangat penting dalam kurikulun di perguruan tinggi negeri. Hal itu disebabkan, pada proses pendidikan yang dilaksanakan di institusi pendidikan akan menciptakan pengusaha baru yang kreatif dan inovatif. Pendidikan kewirausahaan di perguruan tinggi negeri menjadi metode yang paling efektif dalam mempromosikan dan memposisikan image wirausaha mandiri. Kewirausahaan adalah proses untuk menciptakan usaha baru dan organisasi yang baru (Venkataraman, 2000). Sedangkan Niat untuk berwirausaha dapat didefinisikan sebagai keadaan pikiran yang tumbuh secara sadar bahwa seseorang berharap untuk memulai usaha baru atau menciptakan nilai utama demi keberlangsungan suatu organisasi (Remeikiene dan Startiene, 2013).

Isu penting yang menjadi pertanyaan dalam penelitian ini adalah faktor-faktor apakah yang paling dominan pada mahasiswa yang ingin berniat untuk berwirausaha. Banyak penelitian yang menyatakan bahwa pengalaman merupakan faktor yang sangat penting dalam pembentukan mahasiswa berniat untuk berwirausaha (Rhasid, et, al, 2012). Artikel ini mencoba untuk menjelaskan pengalaman berwirausaha yang diperkuat dengan pendidikan menjadi faktor yang berpengaruh pada seorang mahasiswa yang berniat untuk berwirausaha.

\section{B. Tinjauan Teori, Model dan Hipotesis}

\section{Entrepreneurial education}

Pendidikan kewirausahaan merupakan proses pemberian kompetensi kewirausahaan yang terstruktur dan formal mencakup pemberian keterampilan, konsep dan kesadaran mental individu (Alberti dan Poli, 2004). Dengan pendidikan kewirausahaan pola pikir, sikap, dan perilaku mahasiswa akanmenjadi seorang wirausahawan sejati sehingga dapat mengarahkan mereka untuk memilih berwirausaha sebagai pilihan karir (Lestari et al, 2012). Pendidikan kewirausahaan merupakan komponen penting dalam pemberian stimulus kepada individu untuk membuat pilihan karir, sehingga meningkatkan penciptaan usaha baru dan pertumbuhan ekonomi (Alhaji, 2015).

Terdapat lima dimensi pendidikan wirausaha yaitu: tahuapa (know what), tahu kenapa (know why), tahu-siapa (know who), tahu bagaimana (know how), dan tahukapan (know when) merupakan dasar dari pendidikan kewirausahaan: memahami tujuan dari suatu tindakan, kepercayaan diri dan kemampuan untuk mempengaruhi lingkungan personal serta mengembangkan hubungan yang seportif dengan pihak terkait (Johannisson, 1991).

\section{Social support}

Dukungan sosial merupakan interaksi manusia di mana sumber daya sosial-emosional, keterikatan, serta kedekatan dipertukarkan. Pembangunan dukungan social 
berperan penting dalam hasil kesehatan mental karena potensinya untuk melindungi orang-orang dari berbagai gangguan fisik dan psikologis (Cobb, 1976). Dukungan social muncul untuk mengatasi stress, depresi serta masalah kesehatan mental (Gottlieb, 1981). Kurangnya dukungan social akan menyebabkan gejala psikosomatik (Newby-Fraser and Schlebusch, 1997) dan tingginya dukungan social akan mengurangi depresi seseorang (Zimet,Dahlem, et, al, 1988).Dukungan social berperan sebagai sumber yang terdiri dari jaringan teman dan kenalan (social network) guna membantu seseorang dalam mengatasi masalahmasalah sehari-hari atau krisis yang serius (Neergaard, et, al 2005). Dengan begitu, relasi yang baik akan memunculkan perilaku saling mendukung antar anggota organisasi, seperti berapa banyak individu dalam organisasi tersebut merasa masalah pribadi mereka terbantu untuk penyelesainnya (Salanova, Bakker \& Liorens, 2006).

Dukungan sosial (social support) didefinisikan sebagai informasi verbal dan non verbal, saran subyek di dalam lingkungan sosialnya atau yang berupa kehadiran dan berpengaruh pada tingkah laku penerimanya (Gottlieb, 1981). Pendapat lain dukungan social adalah tingkat penilaian individu sejauh mana kebutuhan mereka untuk dukungan, informasi, dan umpan balik dipenuhi oleh teman-teman dan keluarga (Procidano \& Heller, 1983). Orang orang yangmerasa memperoleh dukungan social secara emosional merasa lega karena diperhatikan, mendapat saran atau kesan yang menyenangkan pada dirinya.

Terdapat beberapa 4 (empat) tipe dukungan sosial yaitu emotional support yaitu terkait pengalaman hidup, perasaandihargai, pemberian penghargaan, afeksi, rasa percaya dan perhatian), companionship support yaitu membangkitkan suasana hati yang nyaman, pengalihan perhatian dari masalah, berasal dari teman dekat dan tetangga, tangible support yaitu dukungan biasanya berupa dana, barang, dan kebutuhan yang kongkret, dan informational support yaitu informasi dan pengetahuan yang disediakan guna meningkatkan efisiensi penyelesaian masalah (Neegaard, et, al, 2005).

\section{Entrepreneurial Intention}

Niat kewirausahaan sangat penting untuk memahami proses kewirausahaan, karena niat selalu mendahului pada setiap upaya dalam perilaku kewirausahaan (Alfonso \& Cuevas 2012).Niat adalah keinginan tertentu seseorang untuk melakukan sesuatu atau beberapa tindakan, itu merupakan hasil dari pikiran sadar yang mengarahkan tingkah laku seseorang (Parker, 2004). Niat kewirausahaanmerupakan langkah awal dari suatu proses pendirian sebuah usaha yang umumnya bersifat jangka panjang (Lee \& Wong, 2004). Definisi lain niat kewirausahaan adalah pertumbuhan pemikiran dalam sadar bahwa seseorang berkeinginan untuk memulai usaha baru atau menciptakan nilai inti baru dalam organisasi yang ada (Bygrave, 1989). Niat kewirausahaan mencerminkan komitmen seseorang untuk memulai usaha baru dan merupakan isu sentral yang perlu diperhatikan dalam memahami proses kewirausahaan pendirian usaha baru (Krueger, 1993). Akhirakhir ini niat kewirausahaan mulai mendapat perhatian karena diyakini niat searah dengan perilaku,dan dapat menjadi cerminan dari perilaku 
yang sebenarnya. Faktor-faktor seperti sikap, norma subyektif akan membentuk niat individu selanjutnya berpengaruh secara langsung pada perilaku individu (Fishbein \& Ajzen, 1980). Oleh sebab itu, pemahaman tentang niat individu untuk berwirausaha (entrepreneurial intention) dapat mencerminkan kecendrungan orang untuk mendirikan usaha secara riil (Remeikiene dan Startiene, 2013). Niat untuk melaksanakan perilaku tertentu dapat dipengaruhi oleh beberapa faktor seperti kebutuhan, nilai-nilai, keinginan, kebiasaan, dan keyakinan (Lee dan Wong, 2004).

\section{Pengembangan Model dan Hipotesis}

Berdasarkan tinjauan teori di atas, maka dikembangkan model penelitian sebagai berikut:

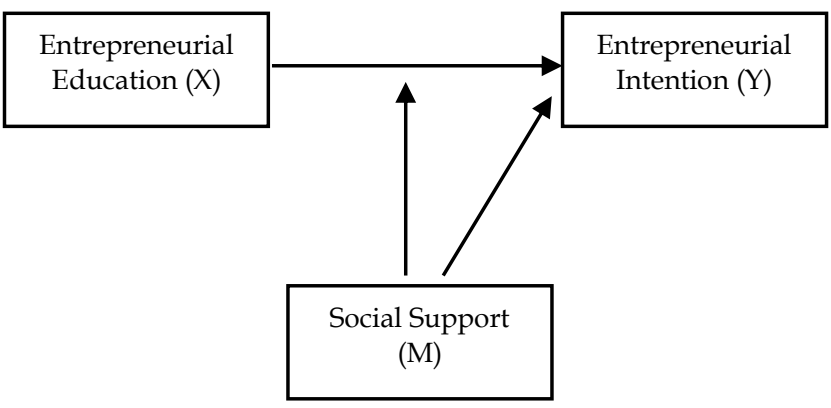

Gambar 1 Model Penelitian

Berdasarkan teori dan penelitian terdahulu yang telah dipaparkan di atas maka dapat ditarik hipotesis penelitian sebagai berikut:

H1: Entrepreneurial education berpengaruh positif terhadap entrepreneurial intention.

H2: Social support berpengaruh positif terhadap entrepreneurial intention

H3: Social support memperkuat pengaruh entrepreneurial education terhadap entrepreneurial intention

\section{Metode Penelitian}

Penelitian ini menggunakan metode eksploratory dengan pendekatan Pendekatan kuantitatif. Lokasi penelitian dilakukan pada 4 (empat) di peguruan tinggi negeri di Bandung. Populasi dalam penelitian ini adalah keseluruhan mahasiswa program studi manajemen S2 yaitu UPI, UIN, UNPAD, dan ITB. Jumlah sampel adalah jumlah indikator dikalikan 5 hingga 10 (Ferdinand, 2002). Pada penelitian ini jumlah sampel yang digunakan sebanyak 130 responden yang diperoleh dari $10 \mathrm{kali}$ 13 indikator. Pengambilan sampel dilakukan dengan teknik probability sampling dengan cara systematic random sampling yaitu pengambilan sampel melibatkan aturan populasi dalam urutan sistematika tertentu. Probabilitas pengambilan sampel tidak sama terlepas dari kesamaan frekuensi setiap anggota populasi.

Teknik analisis adalah moderation regression analysismerupakan metode statistik dalam penganalisaan variable moderasi. Uji moderasi bertujuan untuk mengetahui peran suatu variabel apakah variable moderasi dapat memperkuat atau memperlemah hubungan antara variable independent danvariabel dependent(Hayes, 2013).

Pengukuran sikap individual variable pendidikan wirausaha menggunakan 5 indikator pernyataan Johannisson (1991)dan variabel social support menggunakan 3 item pernyatan dari Gurbuz \& Aykol (2008). Akhirnya, untuk mengukur variabel niat kewirausahaan (enterpreneurial intention) (Liñán et al., 2011; Liñán \& Chen, 2009; Guerrero et al., 2009). Secara keseluruhan, untuk faktor sikap, kontekstual dan niat kewirausahaan, pernyataan diukur dengan menggunakan 5-point Likert 
scale, dimana responden diminta untuk menjawab dengan pilihan angka antara 1-5 (1= sangat tidak setuju, dan $5=$ sangat setuju).

\section{Hasil Penelitian dan Pembahasan}

1. Entrepreneurial education dan Entrepreneurial Intention

Berdasarkan hasil pengujian hipotesis 1 di atas. entrepreneurial education berpengaruh positif terhadap entrepreneurial intention. Dengan kata lain, entrepreneurial education memiliki dampak yang sangat tinggi terhadap entrepreneurial intention mahasiswa. Artinya semakin tinggi entrepreneurial education maka entrepreneurial intention semakin tinggi pula di kalangan mahasiswa. Sehingga terbukti bahwa entrepreneurial education merupakan antecedent dari entrepreneurial intention.

Sebagian besar studi empiris yang disurvei menunjukkan bahwa kewirausahaan dapatdiajarkan, atau setidaknya didorong, oleh pendidikan kewirausahaan (Gorman et al, 1997). Pendidikan kewirausahaan menjadi faktor penting dalam menumbuhkan dan mengembangkan keinginan, jiwa dan prilaku berwirausaha dikalangan generasi muda karena pendidikan merupakan sumber sikap dan niat keseluruhan untuk menjadi wirausahawan sukses di masa depan (Fatoki, 2014). Pendidikan kewirausahaan merupakan usaha sadar yang dilakukan individu untuk menambah wawasan tetang kewirasuahaan (Gerba, 2015). Penjelasan tentang minat mahasiswa untuk melaksanakan wirausaha didasari oleh personal background. Studi tentang gender, pengalaman bisnis keluarga dan tingkat pendidikan merupakan faktor yang sangat berpengaruh terhadap keinginan seseorang untuk berwirausaha (Wang and Wong, 2004)
Pendidikan kewirausahaan berpengaruh positif dan signifikan terhadap niat berwirausaha. Pendidikan kewirausahaan yang dimaksudkan adalah proses pembelajaran untuk mengubah sikap dan pola pikir mahasiswa terhadap pilihan karier berwirausaha (Wijaya, 2012). Penelitian tersebut diperkuat oleh Lestari (2012) bahwa pendidikan kewirausahaan berpengaruh positif terhadap niat berwirausaha. Penelitian lain yang juga mendukung adalah Negash (2013) bahwa pendidikan kewirausahaan berpengaruh positif terhadap niat berwirausaha mahasiswa Ethiopia. Selain itu, penelitian yang dilakukan oleh Lorz (2011) memperkuat penelitian tentang pendidikan wirausaha dapat berpengaruh terhadap niat untuk berwirausaha di Jerman.

\section{Sosial support dan Entrepreneurial Intention \\ Berdasarkan hasil pengujian} hipotesis 2 di atas. Dukungan sosial berpengaruh positif terhadap entrepreneurial intention. Dengan kata lain, dukungan sosial memiliki dampak yang sangat tinggi terhadap entrepreneurial intention mahasiswa. Artinya semakin tinggi dukungan sosial maka entrepreneurial intention semakin tinggi pula di kalangan mahasiswa. Sehingga terbukti bahwa dukungan sosial merupakan antecedent dari entrepreneurial intention.

Salah satu faktor pendukung timbulnya niat untuk berwirausaha adalah Sosiological yaitu menyangkut masalah hubungan dengan keluarga dan hubungan sosial lainya (Alma, 2007). Hubungan keluarga baik itu orang tua, pekerjaan, dan status sosial dapat mempengaruhi niat seseorang untuk berwirausaha. Faktor dukungan sosial dapat berpengaruh 
terhadap niat berwirausaha adalah tanggung jawab terhadap keluarga. Selain itu, Lingkungan dalam bentuk "role model" juga berpengaruh terdapat niat berwirausaha. Role model ini biasanya melihat kepada orang tua, teman-teman, pasangan, atau pengusaha sukses yang diidolakanya. Dorongan teman cukup berpengaruh terhadap semangat berwirausaha, karena kita dapat berdiskusi dengan bebas, dibandingkan orang lain, teman biasa memberi dorongan, pengertian, bahkan bantuan, tidak perlu takut terhadap kritikan, disamping ini ada lagi faktor sosial lainya yang berpengaruh (Yonaevy, 2015).

Dukungan sosial berpengaruh terhadap niat berwirausaha didukung oleh penelitian Wiyanto (2014) yang menyatakan bahwa dukungan social berpengaruh positif terhadap niat berwirausaha Mahasiswa Peminatan Kewirausahaan Program Studi S1 Manajemen Fakultas Ekonomi Universitas Tarumanagara. Penelitian yang sama juga dilaksanakan oleh Suharti dan Sirine (2011) yang menyatakan bahwa dukungan social berpengaruh positif terhadap niat berwirausaha Mahasiswa Universitas Kristen Satya Wacana, Salatiga.

\section{Entrepreneurial Education, Entrepreneurial Intention, dan Social Support}

Berdasarkan hasil pengujian hipotesis 3 di atas Entrepreneurial education dengan dukungan sosial berpengaruh positif terhadap entrepreneurial intention. Dengan kata lain, Entrepreneurial education tinggi yang dirasakan oleh mahasiswa program studi S2 manajemen dapat diperkuat dengan dukungan sosial terhadap entrepreneurial intention mahasiswa. Artinya dukungan sosial memperkuat pengaruh entrepreneurial education terhadap entrepreneurial intention mahasiswa sehingga dalam hal ini terbukti bahwa dukungan sosial merupakan moderating variabel. Mahasiswa yang memilki dukungan sosial (meliputi dukungan dari keluarga) yang tinggi tidak mudah mengalami kejenuhan dalam pendidikan wirausaha. Hal ini disebabkan karena mahasiswa tersebut mampu melaksanakan tugastugas akademik yang diterimanya sehingga mahasiswa dengan dukungan sosial tinggi dapat mengelola pendidikan mereka dengan baik dan memandang pendidikan sebagai faktor yang sangat penting dalam kehidupan mereka (Wiyanto, 2014). Dukungan sosial dari keluarga dapat diartikan sebagai sikap perhatian yang ditunjukkan dalam bentuk kerjasama yang positif, berbagi dalam menyelesaikan urusan serta dapat memberikan dukungan moral amupun emosional terhadap pekerjaan (Dwyer dan Cummings, 2001).

Niat wirausaha mahasiswa telah dijelaskan dalam model dukungan wirausaha (entrepreneurial support model) model ini menjelaskan bahwa dukungan akademik dan dukungan sosial sangat berperan dalam pembentukan individu yang berkeinginan untuk berwirausaha. Selain itu, model dukungan wirausaha menganggap secara dominan dampak dari niat akan berpengaruh terhadap perilaku wirausaha seseorang (Turker dan Selcuk, 2009). Dukungan sosial akan sangat berperan dalam pendidikan wirausaha individu, baik itu dukungan sosial yang berasal dari rekan maupun keluarga yang akan mampu membantu seorang guna mendapatkan feedback yang positif atas pendidikan yang mereka 
laksanakan sehingga mahasiswa dapat memiliki untuk berwirausaha.

\section{E. Kesimpulan dan Saran}

Berdasarkan hasil penelitian, dapat diambil beberapa kesimpulan sebagai berikut:

1. Pendidikan kewirausahaan berpengaruh positif terhadap niat berwirausaha. Artinya, semakin banyak pelatihan kewirausahaan dalam kegiatan belajar mereka maka semakin tinggi pula niat untuk berwirausaha.

2. Social support berpengaruh positif terhadap niat berwirausaha. Artinya, semakin banyak social support dalam kehidupan mereka maka semakin tinggi pula niat untuk berwirausaha.

3. Social support memperkuat hubungan pendidikan wirausaha terhadap niat berwirausaha. Artinya, pendidikan wirausaha berpengaruh terhadap niat berwirausaha yang dimoderasi oleh social support.

Terdapat beberapa saran dalam penelitian ini, antara lain sebagai berikut:

1. Memperhatikan pengambilan data penelitian dengan menggunakan instrumen kuesioner hanyalah menggambarkan pernyataan yang belum tentu menggambarkan kebenaran keadaan diri responden yang sebenarnya, maka dapat disarankan pada penelitian selanjutnya proses pengambilan data perlu memperhatikan situasi dan kondisi responden yang tepat.

2. Bagi para peneliti selanjutnya, peneliti menduga masih terdapat faktor lain yang memungkinkan lebih mempengaruhi niat berwirausaha mahasiswa antara lain: latar belakang bisnis keluarga serta pelatihan bisnis dan lain-lain.

\section{F. Daftar Pustaka}

Ajzen, I. and Fishbein, M. (1980) Understanding Attitudes and Predicting Social Behaviour (Englewood Cliffs, PrenticeHall).

Alberti, F., Sciascia, S., and Poli, A. (2004). Entrepreneurship Education: Notes on an Ongoing Debate. In: 14th Annual Int Ent Conference, Italy, July 4-7.

Alfonso, C., Guzmán \& Cuevas, J. Guzmán

Entrepreneurial intention models as applied to Latin America. Journal of Organizational Change Management. 25 (5), p. 721-735.

Alhaji, Abdul. 2015. Entrepreneurship Education and Its Impact on Self Employment Intention and Entrepreneurial SelfEfficacy. Journal Humanities and Social Sciences. Vol 3. No 1, pp 57-63.

Andrea L. Dwyer dan Anne L. Cummings (2001) Stress, SelfEfficacy, Social Support, and Coping Strategies in University Students. Canadian Journal of Counselling, Vol. 35:3.

Andrew F. Hayes (2013) Introduction to Mediation, Moderation, and Conditional Process Analysis A Regression-Based Approach. New York. The Guilford Press

Buchari Alma. 2007, Manajemen Pemasaran \& Pemasaran Jasa. Bandung: CV. Alfabeta 
Bygrave, W. D. "The entrepreneurship paradigm: a philosophical look at research methodologies"

Entrepreneurship Theory and Practice, vol. 14, no. 1, pp. 7-26, 1989.

Fatoki, Olawale. 2014. The Entrepreneurial Intention of Undergraduate Students in South Africa: The Influences of Entrepreneurship Education and Previous Work Experience. Mediterranean Journal of Social Sciences, 5(7): 294-299.

Ferdinand, Augusty. 2002. Structural Equation Modelling dalam Penelitian Manajemen. Semarang: FE UNDIP.

Gerba, Dugassa Tessema. 2015. The context of entrepreneurship education in Ethiopian universities. Scholarly Journals, 35(3): 225-244.

Guerrero, M., Lavín, J. \& Álvarez, M. (2009).The role of education on start-up intentions: A structural equation model of Mexican university students. Paper presented at the 35th annual conference proceedings of the Association for Small Business and Entrepreneurship.

Gurbuz, G. \& Aykol, S. 2008, Entrepreneurial Inten-tions of Young Educated Public in Turkey. Journal of Global Strategic Management, 4(1): 47-56.

Gottlieb, B. H. (Ed.). (1981). Social networks and social support. Beverly Hills, CA: Sage Publications.

Johannisson, B. (1991). University Training for Entrepreneurship: Swedish Approaches. Journal of Entrepreneurship and Regional Development, 13 (1), 67-82.
Krueger, N. 1993. The Impact of Prior Entrepre-neurial Exposure on Perceptions of New Venture Feasibility and Desirability. Entrepreneurial Theory Practice, 18(1): 5-21.

Lee, S.H. \& Wong, P.K. 2004. An Exploratory Study of Technopreneurial Intentions: A Career Anchor Perspective. Journal of Business Venturing, 19(1): 7-28.

Lestari, R.B dan Trisnadi Wijaya. 2012. Pengaruh Pendidikan Kewirausahaan Terhadap Minat Berwirausaha Mahasiswa di STIE MDP, STMIK MDP, dan STIE MUSI. Jurnal Ilmiah STIE MDP , 1(2): 112-119.

Liñán, F. \& Chen, Y. (2009). Development and cross-cultural application of a specific instrument to measure entrepreneurial intentions. Entrepreneurship Theory $\mathcal{E}$ Practice, May, 593-617.

Liñán, F., Urbano, D. \& Guerrero, M. (2011).Regional variations in entrepreneurial cognitions: Start-up intentions of university students in Spain. Entrepreneurship \& Regional Development, 23(3), 187-215.

Neergaard, Helle, Shaw, \& Carter. (2005) The impact of gender, social capital and networks on business ownership: a research agenda. International Journal of Entrepreneurial Behaviour $\mathcal{E}$ Research Vol. 11 No. 5, 2005.

Negash, Emnet dan Chalchissa Amentin. 2013. An Investigation of Education Student's Entrepreneurial Intention in Ethiopian University: Technology and Bussines Field in Focus. Basic Research Journal, 2(2): 30-35. 
Newby-Fraser, E., \& Schlebusch, L. (1997). Social support, selfefficacy and assertiveness as mediators of student stress. Psychology: A Journal of Human Behavior, 34, 61-69

Maholtra, R. 1993. Guidance for Validity and Reliability Test. Journal of Marketing, Vol 7, pp 231-245.

Michael Lorz (2011). The Impact of Entrepreneurship Education on Entrepreneurial Intention. Dissertation of the University of St. Gallen, School of Management, Economics, Law, Social Sciences and International Affairs. Jerman.

Parker, S. C. 2004. The Economics Of Self-Employment And Entrepreneurship. Cambridge Inggris. Cambridge University Press.

Precidano, M .E . , \& Heller, K. (1983). Measures of perceived social support from friends and from family: Three validation studies. American Journal of Community Psychology, 11, 1-24.

Remeikiene, R. D. and G. Startiene. (2013). Explaining entrepreneurial intention of university students: The role of entrepreneurial education. International Proceedings of the Management, Knowledge and Learning International Conference 2013. [Online]. pp. 299-307.

Salanova, M., Bakker, A B. \& Llorens, S.( 2006) Flow at work: Evidence for an upward spiral of personal and organizational resources. Journal of Happiness Studies. Vol. 7, 1-22.
Sekaran, Uma, 2006, Research Methods For Busines, Salemba Empat Jakarta.

Turker, D., and Selcuk, S. S. (2008), ' Which factors affect entrepreneurial intention of university students? Journal of European Industrial training Vol. 33, No. 2, pp. 142-159.

Wiyanto, Hendra (2014) Dukungan Akademik Dan Dukungan Sosial Sebagai Prediktor Niat Berwirausaha Mahasiswa Studi Pada Mahasiswa Peminatan Kewirausahaan Program Studi S1 Manajemen Fakultas Ekonomi Universitas Tarumanagara.

Wijaya, Tony dan Shanti Budiman. 2013. January 2013. The Testing Of Entrepreneur Intention Model Of Smk Students In Special Region Of Yogyakarta. Journal of Global Entrepreneurship. Vol 4. No. 1.

Zimet, G.D., Dahlem, N.W., Zimet, S.G. \& Farley, G.K. (1988). The Multidimensional Scale of Perceived Social Support. Journal of Personality Assessment, 52, 30-41. 